\title{
A RECONSTRUÇÃO FICCIONAL DO CORPO DE EVA PERÓN NO ROMANCE SANTA EVITA
}

Alejandro González Urrego (UNESP, Araraquara)

Recebido em 22 mar 2016. Alejandro González - Professor titular da Secretaria Aprovado em 29 abr 2016. de Educação de Bogotá, Coordenador do projeto de ensino de inglês na escola básica (GGRP, 2016). Doutor em Estudos Literários (UNESP, 2015). Mestre em Literatura (PUJ, 2010). Licenciado em Línguas Modernas (UD, 1996). Ensino aprendizagem da produção e compreensão de textos em espanhol. Contato: alejo407@yahoo.es

Resumo: O presente artigo propõe a análise ficcional da construção do corpo de Evita no romance Santa Evita, de Tomás Eloy Martínez, tendo como foco a decisiva atuação narrativa baseada nas experiências recuperadas tanto do corpo vivo quanto do corpo embalsamado de Evita, presentes nesse romance. Assim, o objetivo deste artigo é pesquisar a maneira como o narrador-pesquisador Tomás Eloy Martínez constrói uma história ficcional baseada no corpo sequestrado de Evita Perón.

Palavras-Chave: Corpo; Literatura; Memória; História; Ficção.

Abstract: This article proposes the analysis of the fictional construction of Evita's body in the novel Santa Evita, written by Tomás Eloy Martínez, focusing on the narrative decisive action based on the recovered 
experiences of the living body and embalmed body of Evita, both present in this novel. The aim in this article is to research the way how the narrator and researcher, Tomas Eloy Martínez, builds a fictional story based on the kidnapped body of Evita Peron.

Keywords: Body; Literature; Memory; History; Fiction.

O romance do escritor argentino Tomás Eloy Martínez reconstrói ficcionalmente a vida de Eva Perón, esposa do três vezes presidente da Argentina General Juan Domingo Perón, com a justificativa de que o seu corpo embalsamado não pode ser esquecido pelo povo argentino. O tema da ficção está condensado em diferentes formas: arquivos encontrados, documentos e registros oficiais, fitas, anotações, entre outras, que fazem com que o leitor pense que os acontecimentos escritos estão baseados na realidade. Para Givone (2009, p.254), a verdade é reabsorvida pela mentira. E a mentira, essa comédia, essa obscena exibição de si, diz a única verdade humana, verdade horrivelmente humana. A história reconstruída é uma maneira de rejuvenescer e renovar a imagem de Evita pela via da ficção, além de ajudar a cumprir seu último desejo, o de não ser esquecida.

Para além dos procedimentos anteriormente descritos, devemos mencionar a mistura proposital entre a realidade histórica e a ficção. É assim que muitos eventos podem ser trocados, dependendo da intenção do autor, ou repetidamente narrados. Assim, temos o mesmo acontecimento contado a partir de várias testemunhas que viveram o momento junto a Evita, criando diferentes verdades. Com as testemunhas, o autor pretende reunir todos os fragmentos para construir o quebracabeça e dar sentido e significado aos eventos ocorridos com o 
corpo morto, que ficcionalmente adquire poder e se converte em uma ameaça para os oligarcas argentinos.

Segundo Baudrillard (1981), quando o real já não é mais o que era, a nostalgia assume todo o seu sentido. Sobrevalorizações de verdade, de objetividade e de autenticidade passam a um segundo plano. Produções desenfreadas da realidade e do referencial levam à simulação, que é uma estratégia de real, de neo-real e de hiperreal, que leva a uma estratégia de dissuasão.

A estratégia narrativa ficcional de Martínez, feita através dos testemunhos escritos e falados, não deve ser compreendida, pois, como uma descrição da realidade, mas como um exercício de nostalgia. Ainda mais porque, depois de passados muitos anos, o interesse pelas diversas reconstruções da vida de Evita e por seu corpo embalsamado, através da recopilação dos acontecimentos reais, tenta dar uma versão verdadeira dos fatos, mas acaba servindo como uma forma de ficcionalizar a História. "-A un olvido hay que oponerle muchas memorias, a una historia real hay que cubrirla con historias falsas." ${ }^{1}$ (MARTíNEZ, 1995, p.55).

O narrador recolhe os depoimentos de suas testemunhas na primeira pessoa como forma privilegiada para criar a sua verdade. Essa é uma forma de apropriação ficcional, uma estratégia para realizar a reconstrução dos fatos. Dessa maneira, a informação que chega da personagem é fragmentada e distorcida pelas várias testemunhas.

El cuerpo, se dice allí, fue enterrado de pie, como enterraron a Facundo Quiroga. Me detuve. A Facundo,

1 Tradução: "A um esquecimento deve-se opor muitas memórias, uma história real deve ser coberta por histórias falsas" (MARTíNEZ, 1997, p.48). 
pensé, nadie lo enterró de pie. Sentí que me había quedado sin aliento. $^{2}$ (MARTÍNEZ, 1995, p.58).

Segundo Beatriz Sarlo (2007), as experiências testemunhais contadas em primeira pessoa restituem a confiança nos acontecimentos, conservando as lembranças e reparando a identidade machucada. É uma estratégia que os escritores usam para confundir o leitor, e fazê-lo acreditar ainda mais nas histórias ficcionais. Assim, Martínez, depois de pesquisar muitos anos os acontecimentos sobre Evita, começa a elaborar um relato ficcional baseado nas informações colhidas para descrever de modo verossimilhante seu peregrinar antes e após a morte, com o propósito de transformar suas experiências de vida e mostrar outras verdades, criadas.

Lo que sigue, mal que me pese, es una reconstrucción. 0 , si alguien lo quiere, una invención: una realidad que resucita. Antes de escribir estas páginas tuve mis dudas. Cómo hay que contar esto: ¿Alcaraz habla, yo hablo, alguien escucha, o hablamos todos a la vez, jugamos al libre juego de leer escribiendo? ${ }^{3}$ (1995, p.86).

O romance se inicia pelo relato do despertar de Evita de um desmaio que durou mais de três dias. Essa é uma maneira metafórica de o autor dizer que Evita estava em coma, razão pela qual seu corpo sofreu uma grande transformação, devido à gravidade de sua doença. O narrador conta, ainda, como os pobres ficaram em frente

2 Tradução: “O corpo, é o que diz, foi enterrado de pé, como o caudilho Facundo Quiroga. Parei em seco. Facundo, pensei, não foi enterrado de pé, senti que perdera o fôlego" (MARTÍNEZ, 1997, p.51).

3 Tradução: O que segue, ainda que me pese, é uma reconstrução. Ou se preferirem, uma invenção: uma realidade que ressuscita. Antes de reescrever estas páginas tive minhas dúvidas. Como se deve contar isto: Alcaraz fala, eu falo, alguém escuta? Ou falamos todos ao mesmo tempo, jogamos o livre jogo de ler escrevendo? (MARTínEZ, 1997, p.74). 
ao hospital onde Evita estava internada, rezando por sua saúde e esperando que "sua salvadora" ficasse bem.

Paralelamente, a voz narrativa mostra a ação dos oligarcas através do coronel Moori que, nesse tempo, trabalhava para Evita, mas fazia seu trabalho de inteligência, espionando-a por ordem do general da Inteligência que, por sua vez, dizia cumprir ordens de Perón. Com esta ação, os oligarcas demonstram ter medo de Evita, por isso precisavam saber dos movimentos dela para saber como atuar.

Ainda nas primeiras páginas, a protagonista morre, passando a presidir a história por meio de seu corpo embalsamado, como num ritual mágico. Evita é velada durante doze dias, embaixo da cúpula da Secretaria do Trabalho, onde tinha desenvolvido grande parte de sua vida laboral. Paralelamente, o escritor escreve uma irrealidade e a torna crível, afirmando que no dia do enterro de Evita foram espalhadas, das sacadas, um milhão de flores, entre rosas amarelas, alelís dos Andes, cravos brancos e crisântemos, enviadas através de aviões de guerra pelo imperador do Japão. Além disso, o narrador acrescenta que as pessoas tentavam se suicidar aos pés do cadáver com navalhas e cápsulas de veneno. Para criar um enterro majestoso, Martínez escreve que ao lado do prédio funerário foram penduradas dezoito mil coroas de flores. Em todas as capitais das províncias e nas cidades principais foram instaladas representações do velório por meio de fotografias de três metros de altura, objetivando simbolizar a importância que Evita tinha para o povo argentino. O funeral de Evita, nessas condições, nos permite afirmar que a ritualização da morte, neste contexto, é similar ao tempo de festa ou de carnaval na concepção social, é um tempo fora do tempo. 
De acordo com Jean Baudrillard (1981), os "fatos" acontecidos podem ser descritos pela ideia da simulação, com a intenção de romper com qualquer princípio de contradição entre a noção de verdade, originalidade, mentira e falsidade. Dessa maneira, a narrativa propõe que o general Perón mandou embalsamar o corpo de sua esposa com o propósito de fazê-la eternamente lembrada pelo povo. A partir desse momento, o povo começa a acreditar que ela regressará posteriormente como uma santa, guia dos mais necessitados. Nas casas e nas ruas, o povo reunido acende velas, oferece flores, constrói altares e marca um recorde no Guinness com pedidos para que Evita não se esqueça de seus nomes quando encontrar-se com Deus.

O embalsamamento de Evita é, portanto, um ato que visa eternizar sua vida mantendo sua imagem na memória do povo argentino. Dessa maneira, as anotações do doutor Pedro Ara representam ficcionalmente o trabalho de um embalsamador que reconstrói o corpo de Evita só para poder contar a grandeza desse exercício, mas ao mesmo tempo, ele se transforma num biógrafo do corpo e da arte funerária. Verdade e ficção, novamente, se encontram e se confundem, já que,

[a] ficção se passa apenas na cabeça do escritor, mas como estranha ficção que foi dele tomada, assim a sua verdadeira faculdade ficcional não está no fantástico de sua mente, mas sim em que Ihe permite tornar invisível a sua própria ficção. 0 fictício e o imaginário não se deixariam dissociar. O fictício se eleva no imaginário, o imaginário, no fictício. (STIERLE, 2006, p.10)

O engenho do romance consiste em fazer a reconstrução dos acontecimentos ocorridos na vida de Evita, passando pelo 
embalsamamento, terminando com a peregrinação do corpo, aproximadamente nos vinte anos seguintes à sua morte, de forma crível para o leitor. Nesses anos, o povo começa a enviar cartas a Roma pedindo pela santificação de Evita. As pessoas acreditavam que a morte tinha apenas aumentado o poder de Evita. Essa crença foi constatada nas casas humildes, na forma de altares onde as fotos de Evita, arrancadas de revistas, ficavam iluminadas por velas e flores do campo. "En todo el país se alzaron altares de luto, donde los retratos de la difunta sonreían bajo una orla de crespones." ${ }^{4}$ (MARTÍNEZ, 1995, p.185).

Outra forma pela qual, no romance, se ritualiza Evita ainda em vida, ocorre quando seus ajudantes deixam cair cédulas de dinheiro por onde Evita passa de trem: às vezes, ela toma a nota em sua mão, beija-a e a lança ao vento. O narrador conta sobre uma família que tinha uma dessas notas e que a exibia numa moldura, após a morte de Evita. Mesmo que não tivessem o que comer, não a utilizariam, por considerarem-na uma relíquia santa.

Ahora que el billete está fuera de circulación, la familia lo conserva como un objeto religioso, sobre una repisa del comedor, al lado de una foto coloreada de Evita con un vestido largo, de raso negro. Junto a la foto hay siempre un ramo de flores. ${ }^{5}$ (MARTíNEZ, 1995, p.193-194)

Para Gallagher (2009), a ficção, de algum modo suspende, desvia ou segrega qualquer exigência de veracidade em relação 4 Tradução: "Por todo o país foram montados altares de luto, onde os retratos da falecida sorriam sob uma orla de crepes" (MARTínEZ, 1997, p.161).

5 Tradução: Agora que a nota saiu de circulação, a família a conserva como uma relíquia religiosa, sobre uma prateleira da sala de jantar, ao lado de uma foto colorizada de Evita, com um vestido longo de tafetá preto. Ao lado da foto há sempre um ramo de flores (MARTÍNEZ, 1997, p.168). 
ao mundo da experiência ordinária; a ficção torna-se perceptível apenas quando se torna crível, visto que a diferença entre ficções e mentiras se tornara menos óbvia. Nessa linha de pensamento, Martínez propõe, como um elemento ficcional, que o doutor Pedro Ara faz três réplicas, em cera, do corpo embalsamado de Evita, com o objetivo de proteger e esconder dos militares o corpo verdadeiro, criando assim, uma ficção ainda maior que representa por meio da proposta, a multiplicidade de Evita no povo argentino.

Para criar uma trama plausível, o autor de Santa Evita propõe que alguns personagens se apaixonem pelo corpo de Evita, sem saber se ele é falso ou verdadeiro. Evita, morta e embalsamada, teria ficado com os cabelos mais brilhantes, a pele mais lisa e parecia ter quinze anos. O corpo, pois, se converte em objeto de desejo para várias personagens, entre elas, o coronel Moori e mesmo doutor Pedro Ara.

Como el ataúd era enorme y Ella tendía a flotar, la habían inmovilizado con ladrillos: el polvo bermejo teñía lentamente el pelo, la nariz, los párpados. Y aún así, brillaba. Ya el embalsamador, en el puerto, se lo había advertido con una frase estrábica: "Esa mujer brilla tanto como la luna de su voz derecha". Luna o alga o desgracia, la Mujer era fosforescente en las tinieblas de la bodega. ${ }^{6}$ (MARTÍNEZ, 1995, p.324)

Consequentemente, o narrador tem de relatar os três enterros das cópias e o do cadáver verdadeiro, organizados estrategicamente

6 Tradução: como o ataúde era imenso e Ela tendia flutuar, imobilizaram o corpo com tijolos: o pó avermelhado ai tingindo lentamente o cabelo, o nariz, as pálpebras. E ainda assim, brilhava. No porto, o embalsamador já o advertia com uma frase estrábica: "Essa mulher brilha tanto como a lua de sua voz direita". Lua, ou alga, ou desgraça, a Mulher fosforescia nas trevas do porão (MARTíNEZ, 1997, p.279). 
pelo coronel Moori como forma de confundir o Comando da Vingança, versão que, ao final do romance, é desmentida pelo coronel Corominas: "- No hubo copias - dijo Corominas -. Hubo un solo cuerpo. Lo enterró el capitán Galarza en Milán, y desde entonces estuvo ahí, hasta que yo lo recuperé" 7 (MARTíNEZ, 1995, p.389).

Segundo Ara, a primeira cópia de Evita seria enterrada por sua mãe, dona Juana, no cemitério da Recoleta; a segunda seria enviada ao Vaticano e a terceira seria dada ao viúvo. Ao mesmo tempo, a verdadeira Evita seria enterrada por ele próprio, mas nenhum dos eventos descritos foi realizado na narrativa. Ao final, e segundo o romance, o presidente decide que as cópias e o corpo verdadeiro seriam enterrados fora da Argentina e que o encarregado de fazer esses enterros seria o coronel Moori. Também é mencionado no romance que o coronel Moori reconhecia o corpo verdadeiro de Evita por causa de duas marcas feitas nele. A primeira delas seria um pedaço de orelha retirado por ele mesmo e a outra seria a ponta do dedo médio de sua mão, extraída com a ajuda da tecnologia forense.

Uma das personagens de maior destaque nesse momento da história é, evidentemente, o coronel Moori, que recebe um tratamento especial, uma vez que é ele quem fica mais tempo com o corpo. Durante o desenvolvimento da trama opera-se nele uma mudança em relação a esse corpo. O profundo ódio que nutre inicialmente por ela vai desaparecendo, já que ele se apaixona pelo cadáver embalsamado, a ponto de enlouquecer no desenlace da obra.

7 Tradução: “- Não houve cópias - disse Corominas. - Houve um único corpo. Foi enterrado pelo capitão Galarza em Milão, e desde então ficou lá, até que eu o recuperei" (MARTÍNEZ, 1997, p.333). 
Em seu desespero, o coronel enterra um corpo falso de Evita sem se dar conta das marcas que o identificariam como verdadeiro, porque ele acredita vê-las nesse corpo, porém, elas somente existem na mente dele, são invenções dele e o resultado de sua demência.

O mesmo erro também foi cometido pelo Major Arancibia, porém de forma inversa: ele vê as marcas feitas no corpo verdadeiro de Evita e o enterra no cemitério de La Chacarita, com a certeza de que era uma réplica do corpo de Evita. O coronel calculista comete seu gigantesco erro no romance, ao confundir os corpos. Mantendo o erro, ele decide esconder o corpo que acredita ser o verdadeiro nos lugares mais "seguros" e impensáveis. No entanto, em cada um deles, Moori tem que lidar com o mesmo problema: onde quer que coloque o corpo de Evita sempre aparecem flores, as velas acesas e as ameaças do "Comando da Vingança" pressionando para que eles a deixassem em paz. Esse episódio confirma o pensamento de Stierle (2006), para quem o fictício não seria uma disposição simbólica, em que aberturas e rupturas apresentariam o imaginário como outra ficção, senão que o fictício e o imaginário não se deixariam dissociar. O fictício se eleva ao imaginário, e o imaginário ao fictício.

Outro relato meramente ficcional do romance é o peregrinar do corpo embalsamado. Inicialmente, o verdadeiro corpo de Evita fica durante algum tempo dentro de um caminhão em frente ao Serviço de Inteligência. Na sequência, o corpo é levado para o interior do cinema Rialto, permanecendo atrás da tela durante algum tempo e, posteriormente, é levado para o sótão da casa do major Eduardo Arancibia; depois, finalmente, para fora da Argentina, sendo este peregrinar, conforme o ponto de vista literário, uma ilusão cômica. 
Segundo o romance, as três cópias de Evita foram enterradas com nomes falsos nas cidades européias de Rotterdam, Bruxelas e Roma. Mas o mesmo texto afirma que o coronel pegou uma das cópias, acreditando ser o corpo legítimo, que ficou por um mês dentro de uma ambulância em frente à sua casa na Alemanha. Esse corpo será o que, depois, Moori enterrará no quintal da casa dos seus avôs. De acordo com as fontes do narrador, que se apóia em artigos de jornal, ele foi enterrado em um campo, às margens do rio Altmühl, entre Eichstätt e Plunz, ao sudeste da mesma cidade.

Así era como había comenzado el viaje. Galarza debía embarcarse con el cadáver el 23 de abril, en el Conte Biancamano. Fingiría ser Giorgio de Magistris, el viudo desolado de Marta Maggi. Fesquet partiría la noche siguiente en el Cap frió hacia Hamburgo. Se llamaría Enno Köppen y la falsa difunta -la última copia de Persona- iría de contrabando, en el cajón de equipos de radio donde ahora estaba la verdadera. La cubrirían con cables, micrófonos, carretes de grabadores. El doctor Ara repetiría en el cuerpo de vinil y cera la señal estrellada de la oreja y tatuaría en la nuca un cortísimo vaso capilar ${ }^{8}$ (MARTíNEZ, 1995, p.329-330).

É importante ressaltar que a narrativa propõe que enquanto esteve escondido no cinema Rialto, o corpo verdadeiro de Evita é confundido por Yolanda Astorga, filha do Chino, administrador do cinema, com uma boneca que será o seu melhor brinquedo. Dessa 8 Tradução: "Foi assim que a viagem começou. Galarza devia embarcar com o cadáver dia 23 de abril, no Conte Biancamano. Fingiria ser Giorgio de Magistris, o viúvo desconsolado de Marta Maggi. Fesquet partiria na noite seguinte no Cap frio rumo a Hamburgo. Seguiria com o nome de Enno Köppen, e a falsa defunta - a última cópia de Pessoa - iria de contrabando, na caixa de equipamentos de rádio onde agora estava à verdadeira. Iria coberta de fios, microfones, rolos de fitas. O doutor Ara repetiria o sinal estrelado da orelha no corpo de vinil e cera e tatuaria em sua nuca um sutilíssimo vaso capilar" (MARTíNEZ, 1997, p.283). 
forma, esse evento introduz no romance um toque de humor negro, que beira o fantástico, uma vez que a menina costumava brincar, ler e até mesmo dormir com o corpo. De fato, a menina vê o que os especialistas não conseguem ver. Esse corpo é apenas uma boneca de cera.

Mesmo tendo sido reduzida a um corpo embalsamado, Evita Perón, como dissemos, continua exercendo fascínio, principalmente entre os homens. Um exemplo disso aparece no fim do romance quando o coronel Moori chama o cadáver de "persona", por parecer vivo.O processo de loucura de Moori é evidente a partir do momento em que ele deixa o corpo de Evita no cinema Rialto. O segundo indício de insanidade reflete-se na cena em que ele, ao mesmo tempo em que demonstra sua raiva diante do cadáver embalsamado, também deixa transparecer seu desejo amoroso por este.

- ¿Te vas a quedar, Evita? - le preguntó -. ¿Vas a obedecerme? El brillo azul de las profundidades de Persona parpadeó, o él creyó que parpadeaba. ¿Por qué no me querés? - le dijo -. Qué te hice. Me paso la vida cuidándote. Ella no contestó. Parecía radiante, triunfal. Al Coronel se le cayó una lágrima y al mismo tiempo lo alcanzó una ráfaga de odio. Vas a aprender, yegua - le dijo -, aunque sea a la fuerza9 (MARTíNEZ, 1995, p.279).

A partir do momento em que o coronel Moori foi preso e afastado de seu trabalho, por ordens diretas do Governo, e levado a uma zona rural, longe da capital, incomunicável. Assim, o coronel é 9 Tradução: "- Você vai ficar, Evita - perguntou. - Vai me obedecer? O brilho azul das profundezas de Pessoa cintilou, ou ele achou que cintilava. - Por que você não me ama? - disse. $-\mathrm{O}$ que foi que eu fiz? Passo minha vida cuidando de você. Ela não respondeu. Parecia radiante, triunfal. $\mathrm{O}$ coronel deixou escapar uma lágrima ao mesmo tempo em que sentia o golpe de uma rajada de ódio -Você vai aprender, sua égua - disse -, mesmo que seja a força" (MARTínEZ, 1997, p.239). 
separado do corpo de Evita, erroneamente acusado de espionagem, pelas marcas que deixara no caixão e no corpo a fim de que pudesse identificá-lo como verdadeiro.

Moori, entretanto, apaixonado, passa o tempo pensando no corpo. Quando toma conhecimento de que tinha sido levado a Milão, escapa da prisão e vai à sua procura, levando ao extremo sua loucura. Ele rouba o corpo na Europa e o sepulta. Finalmente, o processo de loucura termina quando assiste na televisão e acredita que o corpo foi levado para a lua e foi enterrado pelos americanos lá.

Essa demonstração da insanidade de Moori pode ser achada na passagem do romance onde ele transporta uma das cópias do corpo embalsamado de Evita em uma ambulância e a coloca a seu lado direito, fazendo do cadáver seu acompanhante. Nessa ocasião, quando a polícia para o carro, o coronel diz aos policiais que leva uma "compatriota morta". No entanto, um deles constata que se trata de uma boneca de cera e recomenda ao coronel que não diga que levava uma morta. Contudo, mesmo diante dessa recomendação, Moori continua acreditando que a cópia de cera que leva é o verdadeiro corpo embalsamado de Evita, demonstrando assim, o estágio avançado de sua demência.

Segundo Gallagher (2009), o relato ficcional é imaginado exclusivamente com base em fragmentos descontínuos de linguagem; os leitores devem concentrar-se mais intensamente nas relações dinâmicas internas desses fragmentos do que o fazem quando lêem obras não ficcionais, ainda que, por vezes, elas empreguem técnicas semelhantes para apresentar hipóteses sobre pensamentos não expressos pelas pessoas. Dessa forma, 
no romance, o corpo fragmentado vai se construindo como uma narrativa também fragmentada.

Evita, já morta, é um corpo embalsamado que não se deixa esquecer. O corpo dela se converte em algo vivo que, em uma ocasião, em frente ao coronel, dá sinais de vida, emitindo gases e líquidos, como querendo advertir que está contrariado com o abuso de poder do coronel e que resiste às suas ordens. Assim, ao lado do coronel Moori, o corpo embalsamado oferece outra versão dos acontecimentos e o leitor começa a ter clareza de sua divindade. Ele não aceita o destino que lhe oferece o coronel, símbolo das oligarquias, e continua agindo de acordo com suas crenças no peronismo, como se ele conservasse lembranças de quando estava vivo.

Tendido sobre el cristal, el cuerpo de Evita se resistía sin embargo a las órdenes y actuaba según su propia lógica funeraria. Las fosas de la nariz empezaban a destilar gases azules y anaranjados. ¿Y ahora qué le pasa?, se preguntó el Coronel. Está perfecta, no necesita nada. No sufre de pesadillas ni de frío. No la molestan las enfermedades ni las bacterias $^{10}$ (MARTíNEZ, 1995, p.133).

Outro evento produzido pelo autor é a maldição sofrida por todos aqueles que tiveram contato direto com o corpo. É assim que os oficiais encarregados de cuidar dele morrem, adoecem ou sofrem acidentes. O coronel Moori fica louco e Galarza, responsável por transportar o corpo até o cemitério, é vítima de um acidente. O major Arancibia mata sua esposa acidentalmente quando o corpo de Evita

10 Tradução: "Deitado sobre o cristal, o corpo de Evita, entretanto, resistia às ordens e agia segundo sua própria lógica funerária. Suas fossas nasais começavam a destilar gases azuis e alaranjados. E agora que está acontecendo? Perguntou-se o Coronel. Está perfeita, não precisa de nada. Não tem pesadelos, não sente frio. Não é importunada pelas doenças nem pelas bactérias" (MARTíNEZ, 1997, p.116). 
está em sua casa: ele a confunde com um ladrão do "Comando da Vingança" que estaria lá para pegar o corpo. Assim, ele termina preso e isolado. Além disso, os soldados que vigiam o corpo de Evita dentro de um furgão, depois que este foi desenterrado em 1974 na cidade de Madri, também caminham para um destino trágico. Por causa de uma dívida de jogo, eles atiram uns nos outros e acabam morrendo.

Outro estranho evento acontece quando o corpo de Evita é transportado em outubro de 1976 da residência presidencial até o cemitério da Recoleta. Naquela ocasião, o motorista, sargento Justo Fernández, sofre um infarto e os soldados da escolta rasgam suas jugulares com as baionetas. No entanto, em todos esses eventos trágicos, o corpo de Evita não sofre dano algum, nem sequer um arranhão. Através desses estranhos eventos no romance, o autor ficcionaliza, pois, a realidade dos eventos históricos.

"Si usted me andaba buscando, ya no me busque. Si usted va a contar la historia, tenga cuidado. Cuando empiece a contarla, no va a tener salvación". Ya había oído antes esa advertencia y la había desdeñado. Era tarde ahora para echarme atrás ${ }^{11}$ (MARTíNEZ, 1995, p.77).

Martínez usa a metáfora dos "zumbidos das abelhas" para representar a onipresença da protagonista e como os pobres não a esqueciam; localizando-a sempre, apesar dos esforços do coronel Moori para ocultar o cadáver.

Também de maneira ficcional, o narrador, agora personagem, começa a sonhar com Evita. Nesses sonhos, ela aparece como uma

11 Tradução: "Se o senhor estava me procurando, não procure mais. Se vai contar a história, tenha cuidado. 'Quando começar a contá-la, não vai ter mais salvação' Eu já ouvira antes aquela advertência e a desprezara. Agora era tarde demais para voltar atrás" (MARTíNEZ, 1997, p.66). 
grande borboleta, com uma asa preta e a outra amarela, voando para trás. Essa é também a direção da história narrada em seu livro. A morte vai para frente, e a história da vida de Evita, avança para trás. Para Hutcheon (1991), a inserção do autor no texto é um dos rasgos estilísticos que determinará a qualidade pósmoderna do romance. Ele se transforma em meta-relato acerca da impossibilidade de narrar e reflexionar sobre a representação da sua função ideológica da História.

Outro elemento ficcional presente no romance é a suposta santidade de Evita ou o desejo da classe mais pobre argentina de canonizá-la. Assim, no romance é mencionado que desde que Evita era viva, até ano e meio depois de sua morte, quarenta mil cartas foram enviadas ao Vaticano atribuindo a ela algum milagre para justificar o pedido de canonização, perante as quais, o Prefeito da Congregação para a Causa dos Santos respondia com as fórmulas de praxe: "Cualquier católico sabe que para ser santo hay que estar muerto". Y después, cuando ya la estaban embalsamando: "Los procesos son largos, centenarios. Tened paciencia."12 (MARTíNEZ, 1995, p.66).

Não faltavam justificativas entre o povo argentino para canonizar Evita. Segundo o romance, embora soubesse que Maria Goretti esperara pela santificação quarenta e oito anos e Teresa Lisieux pouco mais de vinte e cinco, o povo acreditava que Evita merecia uma atenção especial porque só a Virgem Maria a superava em virtudes e o fato de o Sumo pontífice demorar a admitir uma santidade tão evidente era uma ofensa para sua fé.

12 Tradução: "Qualquer católico sabe que para ser santo é preciso estar morto" e, depois de morto, "Os processos são longos, centenários, tende paciência" (MARTíNEZ, 1997, p.57). 
Desse modo, em seu romance, Martínez faz com que Evita apareça como uma emissária de Deus. Para enfatizar essa ideia, o autor menciona que alguns camponeses viram a face de Evita desenhada no céu, e que os pobres faziam coisas inacreditáveis para ajudar sua salvadora, como a menina Evelina que, informada sobre a indicação de Eva Perón à vice-presidência e que os generais e opunham por recusarem-se a receber ordens de uma mulher, escreveu milhares de carta e uma última com apenas três palavras: "Que vivan las mujeres"13 (MARTíNEZ, 1995, p.68). Posteriormente, a menina se exibiu com a carta na vitrine de uma loja de móveis, ocasião em que reuniu tanta gente que a vidraça do estabelecimento foi quebrada pela multidão. Além disso, para pressionar o governo, a jovem Evelina se retirou para a praia, juntamente com outras personagens, e entrou em greve de fome. Eram vésperas da Semana Santa e depois de um furioso temporal que arrancou as árvores pela raiz, Evelina teve um final trágico, desaparecendo sem deixar vestígios.

Mi querida Evita, no boi a pedirte nada como asen todos por aqi, pues lo unico qe pretendo es que leas esta carta y te acordes de mi nombre, yo se qe si vos te fijas en mi nombre aunqe sea un momentito lla nada malo me podra pazar y yo sere felis sin enfermedades ni pobresas. Tengo 17 anio y duermo en las colchone que la otra nabidad dejastes de regalo en mi casa. Te qiere mucho, La ennosa Evelina. ${ }^{14}$ (MARTínEZ, 1995, p.68)

13 Tradução: "Que vivam as mulheres." (MARTíNEZ, 1997, p.59).

14 Tradução: Minha querida Evita, não vou ti pedir nada como todo mundo fais por aqi, pois o qe eu pretendo é só qe si você leia esta carta e lembri do meu nome; eu sei qu você reparar no meu nome, nem qe seja um momentinho, nunca mais vai poder mi acontecer nada di mau, e eu vou ser felis sem doensas nem pobresa. Tenho 17 anos e durmo nos colchões que no natau passado você deixou lá em casa de presente. Ti ama muito, a linda Evelina. (MARTíNEZ, 1997, p.59). 
Martinez também relata que quando membros do povo tiveram certeza de que Evita iria morrer a qualquer momento, milhares deles começaram a fazer os mais exagerados sacrifícios para que seus nomes fossem repetidos por Evita frente ao criador. A cada duas ou três horas, o número de devotos batia um novo recorde mundial de trabalho ininterrupto. Um desses casos foi o do jogador de bilhar, Leopoldo Carreras, que fez mil e quinhentas cambalhotas, sem parar, no átrio da basílica de Luján. Além disso, nas igrejas, havia milhares de pessoas que ofereciam suas vidas pela de Evita ou que suplicavam às cortes celestiais que a recebessem com honras de rainha.

Também de modo ficcional, o autor descreve a fortuna que Evita tinha deixado depois de morrer: 1200 barras de ouro e prata, 756 objetos de prataria e ourivesaria, 650 jóias, 144 peças de marfim, colares e broches de platina, diamantes e pedras preciosas avaliadas em 19 milhões de pesos, além de bens imóveis e ações de estabelecimentos agrários em comum com o general Perón, cujo valor atingia os 16 milhões de pesos.

$\mathrm{Na}$ perspectiva de Henry James (1995), o romance precisa ser levado a sério para que o público o leve a sério também. A velha superstição sobre a ficção ser injusta sem dúvida acabou no passado; mas seu espírito subsiste num certo olhar atravessado que se dirige a qualquer história que não admita ser somente uma anedota. Assim, e para enfatizar o caráter sério de seu romance, mesmo na introdução de elementos fantásticos ou dificilmente comprováveis historicamente, o narrador detalha os acontecimentos para fazê-los verossímeis. 
Um exemplo disso é quando Martínez afirma que nos meses seguintes à morte de Evita, no prédio da Coordenadoria Geral do Trabalho CGT, onde seu cadáver foi embalsamado em um laboratório improvisado e permaneceu por três anos, sempre apareciam flores às 20h25min, hora da morte de Evita; as luzes das janelas se acendiam e se apagavam intermitentes, até que um dia a cortina que pendia da janela despencou, graças aos temporais. A maneira instigante e misteriosa como se produzem esses acontecimentos coincide com a queda de Perón e, frente a isso, o narrador vaticina um futuro incerto, mas ninguém sabe a que futuro ele se refere.

Esses acontecimentos estranhos coincidem no livro com a chamada "Revolução Libertadora", ou com a chegada dos oligarcas ao poder, depois da queda de Perón. Esses novos nomes decidiram, através de um decreto, eliminar toda memória do peronismo. Ficava, portanto, proibido elogiar em público Perón e Evita, mostrar suas fotografias ou mesmo, lembrar-se de sua existência:

Se reprimirá con pena de seis meses a tres años a todo el que deje en lugar visible imágenes o esculturas del depuesto dictador y su consorte, use palabras como peronismo o tercera posición, abreviaturas como PP (Partido Peronista) o PV (Perón vuelve), o propale la marcha de esa dictadura excluida. ${ }^{15}$ (MARTíNEZ, 1995, p.164)

Segundo James (1995), os eventos que o autor narra num romance de ficção não aconteceram realmente. O escritor está menos preocupado em procurar a verdade do que o historiador;

15 Tradução: "Será condenado à pena de seis meses a três anos todo aquele que deixar em local visível, imagens ou efígies do deposto ditador e sua consorte, usar palavras como peronismo ou terceira posição siglas como PP (Partido Peronista) ou PV (Perón Volta), ou propalar a marcha da ditadura proscrita." (MARTíNEZ, 1997, p.142) 
a tarefa para ele deve representar e ilustrar os acontecimentos do passado do homem, mas com uma dificuldade maior do que o historiador, porque também deve coletar as provas, que não são somente literárias. Martínez recolhe provas que parecem irrefutáveis e refuta tais provas. Assim, ao final do romance, aparece o Coronel Túlio Ricardo Corominas, uma nova testemunha, com outra versão dos acontecimentos narrados.

O Coronel, como dissemos, não concorda com os dados fornecidos no romance, mas o narrador Martínez, que nesse trecho se apresenta como uma personagem do romance, tenta Ihe explicar que sua narrativa é um romance. Contudo, Corominas não acredita nisso e expressa que o que valem são os fatos de verdade. "Es una novela -expliqué-. En las novelas, lo que es verdad es también mentira. Los autores construyen a la noche los mismos mitos que han destruido por la mañana."16 (MARTíNEZ, 1995, p.389).

Segundo Beatriz Sarlo (2007), os relatos ficcionais narrados na primeira pessoa não se podem diferenciar da ficção, os leitores podem acreditar nos feitos ou o mesmo escritor pode escrever com essa ilusão, mas nada garantirá se é ficção ou uma realidade vivida, histórica. Exemplificando tal pensamento, Santa Evita se apresenta como um balanço entre verdade, mentira, História e ficção, tendo como suporte a reconstrução ficcional do corpo de Eva Perón, que transita entre o sagrado e o profano, entre a História e a invenção.

Faltava uma categoria conceitual de ficção, no sentido de histórias críveis que não tivessem a pretensão de serem tomadas por verdadeiras.

16 Tradução: "É um romance - expliquei. - Nos romances, o que é verdade também é mentira. Os autores constroem à noite os mesmos mitos que destruíram pela manhã." (MARTÍNEZ, 1997, p.333) 
Foi o novel que proporcionou a junção das duas coisas, fato que explica a relação paradoxal que mantêm com a ficção. Esta, com efeito, torna-se perceptível apenas quando se torna crível: visto que a diferença entre ficções e mentiras tornarase menos óbvia, e a ausência de credibilidade não era mais o único critério distintivo, fez-se necessária uma verdadeira conceituação. A ficção elaborou um discurso próprio ao tornar-se menos vistosa: quanto menos era evidente, mais tinha necessidade de emergir como categoria conceitual (GALLEGHER, 2009, p.634-635).

Conclui-se aqui que os eventos narrados por Tomás Eloy Martínez são uma reconstrução ficcional do corpo embalsamado de Evita, baseada nos acontecimentos da sua vida e o peregrinar do corpo nas mãos dos militares. Assim, a partir da memória coletiva que está radicada no povo argentino, Martínez toma da ficção os elementos necessários para fazer uma história mais verossímil que muitos fatos da História oficial, em que as obsessões das oligarquias e dos militares de perder o poder os levaram a tomar medidas extremas e absurdas.

\section{REFERÊNCIAS}

BAUDRILLARD, Jean (1981). "A Precessão dos Simulacros". In: Simulacros e simulação. Lisboa: Relógio d'Água.

GALLAGHER, Catherine (2009). "Ficção". In: MORETTI, Franco (Org.). O romance 1: A cultura do romance. Tradução de Denise Bottman. São Paulo: Cosac Naify. p.629-658.

GIVONE, Sergio (2009). Dizer as emoções. A Construção de Interioridade no Romance Moderno. In: MORETTI, Franco (Org.). O romance 1: A cultura do Romance. Tradução de Denise Bottmann. São Paulo: Cosac Naify. 
HUTCHEON, Linda (1991). Poética do Pós-Modernismo: História, Teoria, Ficção. Tradução de Ricardo Cruz. Rio de Janeiro: Imago Editora.

JAMES, Henry (1995). A Arte da Ficção. Seleção e apresentação: Antonio Paulo Graça; Tradução de Daniel Piza. São Paulo: Imaginário.

MARTÍNEZ, Tomás Eloy (1995). Santa Evita. Buenos Aires: Biblioteca Del Sur Planeta.

- (1995). Santa Evita. Tradução de Sérgio Molina. 4.ed. São Paulo: Companhia Das Letras.

SARLO, Beatriz (2007). Tempo passado. Cultura da Memória e Guinada Subjetiva. Tradução de Rosa Freire D’Aguiar. São Paulo: Cia. Das Letras; Belo Horizonte: UFMG.

STIERLE, Karlheinz (2006). A Fiç̧ão. Novos Cadernos do Mestrado. Tradução de Luiz Costa Lima. Rio de Janeiro: Caetés. 